Southern Illinois University Carbondale

OpenSIUC

Honors Theses

University Honors Program

2003

\title{
Diversity and Community Structure of Littoral Zone Macroinvertebrates in Southern Illinois Reclaimed Surface Mine Lakes
}

Thomas Heatherly II

Follow this and additional works at: http:/ / opensiuc.lib.siu.edu/uhp_theses

\section{Recommended Citation}

Heatherly II, Thomas, "Diversity and Community Structure of Littoral Zone Macroinvertebrates in Southern Illinois Reclaimed Surface Mine Lakes" (2003). Honors Theses. Paper 255.

This Dissertation/Thesis is brought to you for free and open access by the University Honors Program at OpenSIUC. It has been accepted for inclusion in Honors Theses by an authorized administrator of OpenSIUC. For more information, please contact opensiuc@lib.siu.edu. 


\title{
Diversity and community structure of littoral zone macro- invertebrates in southern Illinois reclaimed surface mine lakes
}

\author{
Thomas Heatherly II
}

ABSTRACT/ I sampled fourteen reclaimed surface mine lakes within the Sparta Illinois National Guard training facility for benthic macroinvertebrates in spring of 2003 as part of an overall environmental assessment of the property. The objectives of this research were: (1) to inventory the aquatic macroinvertebrates present; (2) to evaluate the current quality of the aquatic habitats so that the effects of subsequent management and development by the National Guard can be assessed; (3) examine which factors influence invertebrate community structure in these systems; and (4) observe the applicability of several commonly used stream bioassessment metrics to Midwestern surface mine lakes. A dip net was swept over 2 or 3 two-meter transects of littoral zones of each lake, from which 300 macroinvertebrates were randomly removed following rapid bioassessment protocols. Macroinvertebrates were identified primarily to genus and a multimetric approach was used to examine community structure and tolerance. Oligochaetes were typically the most abundant taxon, followed by Hyallela, Chironomidae, Physa, and Caenis. I used a principal components analysis and forward stepwise multiple regressions to examine the effects of several lake variables on diversity metrics. Simpson diversity was positively correlated $\left(\mathrm{r}^{2}=0.92, P=\right.$ 0.0003) with lake area, percent rock and gravel substrate, Simazine concentration, bank slope, and transparency. Percent collector-gatherer and percent predator metrics were negatively correlated $(\mathrm{RSq}=0.93)$, suggesting that each will only be abundant in the absence of the other and also that other functional groups were poorly represented in these systems or are represented by organisms other than macroinvertebrates. Additionally, percent predators were positively correlated $\left(r^{2}=\right.$ $0.89, P=0.0018$ ) with chlorophyll $a$, alkalinity, and atrazine concentration while percent collector-gatherers were negatively correlated $\left(r^{2}=0.83, P=0.0055\right)$ to these same variables. Species richness, Shannon diversity, percent insect taxa, and percent contribution by the dominant taxon all proved to be practical indices for this study, while a Hilsenhoff index and EPT (Ephemeroptera, Plecoptera, and Trichoptera) did not show enough variability to be useful. 
Key Words: aquatic macroinvertebrates, biological assessment, functional groups, strip-mine lakes, littoral

\section{Introduction}

A reclaimed surface mine lake is formed when mining activity ceases and groundwater removal is abandoned. Hundreds of these lakes were created in the Midwest during the first half of the twentieth century as a result of the mining of coal (Castro and Moore, 2000). Much of the extensive coal mining activity that occurred in this region was arrested with the passing of the Surface Mining Control and Reclamation Act of 1977 which severely restricted the conditions in which mining was permissible. Additionally, much of the coal in southern Illinois is rich in sulfur, a major contributor to acid rain.

However, technological advancements have made the cleaner burning of sulfurrich coal possible, while poor local economies have prompted efforts to implement these practices. The southern Illinois coal mining industry will likely be rejuvenated in the immediate future. As a result, it is expected that even larger volumes of water will be contained within reclaimed surface mining lakes, which makes it important to understand the diversity, structure, and function of the organisms within them.

A lake that has formed in a coal mining pit tends to be different from natural lakes. Natural lakes are usually shallower with a surface area to depth ratio less than $2 \%$. In comparison, strip-pit lakes often have ratios approaching $40 \%$ (Miller and others, 
1996; Doyle and Runnells, 1997; Castro and Moore, 2000). This is important because the relation between depth and surface area is often the most important factor determining water circulation (Anderson and others, 1985; Doyle and Runnells, 1997; Wetzel, 2001). Lakes that have smaller surface area to depth ratios are more likely to experience seasonal turnovers which keep the entire water column oxygenated. In contrast, a lake that is very deep relative to its diameter may become permanently stratified. This may result in a condition called meromixis in which an anoxic bottom layer of water called the monimolimnion becomes dense to the point that there is not enough energy in the system to mix this layer (Hutchinson, 1957; Doyle and Runnels, 1997; Wetzel, 2001).

Pit lakes also have different morphologies than reservoirs. Reservoirs are typically more heterogeneous than strip-pit lakes and they often have at least seasonal inflows from lotic systems. The combination of flooding and loading in reservoirs may lead to turbidity and eutrophication (Thornton and others, 1991; Baxter, 1997; Rosenberg and others, 2000). In contrast, strip mine lakes usually have little shore development, few natural features, and drain much smaller landscapes. This means that the morphology of a strip mine lake is more conducive to clearer water, but the actual water quality appears to be more often a function of the immediately surrounding land use.

Reclaimed surface mine lakes have received much attention in the areas that directly affect ecological, municipal, and recreational use, such as acid-leaching, water chemistry, and fish communities (e.g. Miller and others, 1996; Davis and Eary, 1997; Doyle and Runnells, 1997; Castro and Moore, 2000). No studies have been done, however, concerning the composition or diversity of the littoral zone macroinvertebrates 
of these lakes or their responses to the unique environmental factors that comprise these systems.

Aquatic macroinvertebrates are an important conduit between primary producers and detritus and higher consumers (Hanson, 1990; Boisclaire and Leggett; 1985). They make available to large organisms like fish and waterfowl the photosynthetic energy that is harnessed by primary producers and detritivores. This is an extremely important link in aquatic systems and has been overlooked in mining lakes.

Macroinvertebrate analyses are also a powerful tool for assessment of aquatic systems. They integrate chemical, physical, and biological stresses over space and time, they are excellent indicators of ecosystem health because they respond predictably to many perturbations, and they are often easier and less expensive to analyze than chemicals or fish (Gerritson and others, 1998; Barbour and others, 1999; Whiles and others, 2000).

The Sparta National Guard training facility contains a series of reclaimed surface mine lakes that have many differences, which include fish community structure, algal production, and herbicide contamination (Garvey and others, 2003 unpubl; Lydy and others, 2003 unpubl), while still maintaining the same basic profile: they are all deep, relatively clear lakes with little shore development. This combination resulted in an excellent opportunity to observe the factors that contribute to the benthic macroinvertebrate diversity in strip mine lakes. My objectives were to inventory the littoral zone macroinvertebrates, statistically analyze how these invertebrates responded to numerous measured variables, compile information that may be useful for future bioassessment efforts in these systems, and apply common stream bioassessment metrics 
to these lakes. In particular, I felt that it was important to focus on how the more restricted littoral area of these lakes, due to their often extremely steep slopes, affected the macroinvertebrate communities that live in the diverse littoral habitat.

\section{Study Area}

This research was conducted from fourteen reclaimed surface mine lakes within a property recently purchased by the Illinois National Guard in northeast Randolph County, Illinois. This 2,800 acre plot was mined for coal and the pits filled with groundwater approximately twenty years ago. This property is intended for use as a training facility by the Illinois National Guard, which funded an environmental assessment of the aquatic and terrestrial habitats so that management and development activities may be monitored.

This portion of southern Illinois was once where the native tallgrass prairie peninsula formed a mosaic with the central U.S. mixed hardwoods ecoregion. The majority of land is now used for agriculture. Most of the terrestrial landscape within the research area is covered by exotic species of $\mathrm{C} 3$ grasses, but a few places have tree coverage (Figure 1).

Three of the sampled lakes (L1-L3) are large, with areas from 36 to 56 hectares, and the remaining 11 (S2-S12) are smaller, from 1.4 to 8.8 hectares (Figure 1). The three large lakes have maximum depths from 25 to 29 meters with a mean of 26.67 meters. The maximum depth of the smaller lakes ranges from 3 to 11 meters with a mean of 7.6 meters. Winter 2003 dissolved oxygen data (Garvey and others, 2003 unpubl) show that these lakes are not permanently stratified as may happen in strip lakes of the western United States (Miller and others, 1996; Davis and Eary, 1997; Doyle and Runnells, 1997; 
Castro and Moore, 2000). As of April, 2003, many of the smaller lakes had already experienced stratification with thermocline depths between 5 and 6 meters. The Sparta lakes also do not have the problems with acidity that characterize the copper and gold mine lakes of the western United States (Miller and others, 1996). In fact, the $\mathrm{pH}$ for these lakes never strayed from a range of $8.0-8.5$ (Lydy and others, unpubl) due to the introduction of limestone blocks and from the natural soft rock of the region which both serve to enhance acid buffering capacity (Miller and others, 1996; Castro and Moore, 2000; Wetzel, 2001).

All of the lakes have a relatively limited littoral zone area due to steeply sloping banks. The low/mid order Plum Creek runs through the northern edge of the property (figure 1) and frequently floods into the bordering lakes during spring storm events. Electrofishing has shown that many of the lakes were stocked with game fish, especially largemouth bass (Micropterus salmoides) and bluegill sunfish (Lepomis macrochirus); while some species, such as freshwater drum, were likely introduced from Plum Creek during flood pulses (Garvey and others, unpubl).

\section{Methods}

Macroinvertebrate Sampling and Identification

Two macroinvertebrate samples were taken from each of the smaller lakes (S2S12) and three samples were taken from each of the large lakes (L1-L3) during April and May, 2003 (Figure 1). Lake S1 was not sampled for macroinvertebrates due to inaccessibility. Individual sample sites were chosen that were most representative of the conditions of the lake. For example, a lake that was sampled twice had transects that best 
represented fifty percent of the lake's shoreline habitat. The banks had little natural structure, therefore transect choice was often based on the best representation of the algal and/or macrophyte communities. There was commonly a mixture of submerged vegetation and macroalgae along the shore which served as the most suitable representative for a transect. A fence post was driven into the substrate at the water edge of each transect as a permanent marker. A $500 \mu \mathrm{m}$ mesh, $0.3 \mathrm{~m}$ by $0.5 \mathrm{~m}$ dip net was used to make two parallel, non-overlapping sweeps along a two-meter transect perpendicular to the shore. The net was bumped along the substrate beginning two meters from shore to collect shallow burrowing species as well as those in the water column and among the vegetation. Samples were immediately rinsed and preserved in $10 \%$ formalin solution. Three-hundred macroinvertebrates were randomly removed, when possible, from each sample using a gridded pan and random number table according to USEPA rapid bioassessment protocols (Barbour and others, 1999). With the exception of the Chironomidae and several non-insect taxa, most organisms were identified to genus using Merritt and Cummins (1996) or Smith (2001).

\section{Habitat Analysis}

A two by two-meter grid was centered over each transect. Submergent and emergent vegetation cover was estimated and a densiometer was used to measure percent canopy cover. Water depth was measured with a meter stick every $0.5 \mathrm{~m}$ between the shore and fencepost to calculate the slope and mean depth of each transect. A substrate grab was also taken every $0.5 \mathrm{~m}$ at the point of meter stick contact to visually estimate substrate composition according to a modified Wentworth scale (Cummins, 1962). 
Water Chemistry, Fish Communities, and Water Toxicology

Water chemistry data were collected with a Van Dorn water bottle, fluorometer, Hach digital titrator, and Hydrolab Quanta. Two samples were taken from lakes S2-S12 and three samples were taken from lakes L1-L3 (Lydy and others, unpubl).

Fish data were collected using the catch per unit area for 60 minutes of electrofishing (Garvey and others, unpubl). All sizes and weights were recorded.

Water toxicology data were collected by testing tissues from ten fish retained from the electrofishing. Also, six sediment samples and two or three water samples (two from S2-S12 and three from L1-L3) were tested for organochlorine pesticides (Lydy and others, unpubl).

\section{Data Analysis}

I calculated taxa richness; Simpson diversity and evenness; Shannon diversity and evenness; Hilsenhoff's Biotic Index (Hilsenhoff 1987); \% Oligochaeta; \% Chironomidae; EPT (Ephemeroptera, Plecoptera, and Trichoptera); and \% functional structure. Functional group designations were based on Merrit and Cummins (1996) and Smith (2001). I used a principal components analysis to check for redundancies in these metrics as well as in physical habitat, chemistry, and fish data. Stepwise multiple regression models were used to identify the responses of metrics to variables. Simple linear regressions were used to examine the relationships between predatory and gatherer functional groups as well as individual taxon response to variables. 


\section{Results}

Macroinvertebrate Assemblages

I identified 42 benthic macroinvertebrate taxa from among the 14 lakes. There were 31 insects, 4 annelids, 4 mollusks, and 3 crustaceans. Appendix 1 lists taxa and distributions. The number of taxa identified from an individual sample ranged from 8 to 19 , with a mean value of 11.64 taxa per sample $(n=31, \mathrm{SE}=0.50)($ Appendix 1$)$. Oligochaetes accounted for $40 \%$ of the total invertebrates collected, and were the dominant taxon in 20 of all 31 samples (Appendix 1). Lake S7 was the most dominated by oligochaetes at $85 \%$.

Hyallela sp. was the second most abundant taxon collected at $22 \%$ of the total invertebrates, and was the dominant taxon in 6 samples (Appendix 1). All of the lakes where Hyallela were abundant had higher than average concentrations of atrazine (Appendix 3), although this relationship was not significant.

The most abundant insect taxon was Chironomidae, which was also the third most abundant overall taxon (Appendix 1). Chironomids were the dominant taxon in 5 samples and comprised $13 \%$ of the total invertebrates collected. No other taxa were dominant in any of these lakes, but Physa sp., Caenis sp., Enallagma sp., and Helisoma sp. were common (each $>2 \%$ of the total taxa).

\section{Community Metrics}

A multiple regression model showed that the dominance metric was negatively affected by lake area and the percentage of rocky substrate (Table 1). Shannon diversity, on the other hand, was positively related to the percentage of rocky substrate and lake 
area (Table 1). Shannon diversity values ranged from 0.67 in S7 to 1.99 in L3, with a mean of $1.41(\mathrm{SE}=0.62)$. Simpson diversity values $(0-1$ with zero being most diverse $)$ ranged from 0.17 in $\mathrm{S} 6$ to 0.71 in $\mathrm{S} 7$ (Table 1), and the mean was $0.36(\mathrm{SE}=.025)$. An aggregate of five variables, also including rocky substrate and lake area, were correlated with Simpson diversity (Table 1). S7 was the least diverse lake according to both diversity metrics and was the most dominated by a single taxon. Generally, stronger relationships were observed using Simpson diversity than with Shannon diversity.

The percent of predatory taxa was positively related $\left(\mathrm{r}^{2}=0.89, P=0.0018\right)$ to chlorophyll $a$, atrazine concentration, alkalinity, and sunfish (Centrarchidae) abundance. Common predators were Enallagma sp., Libellula sp., and several aquatic beetles. The percentage of gatherer taxa was negatively $\left(\mathrm{r}^{2}=0.83, P=0.0055\right)$ related to chlorophyll $a$, atrazine concentration, Secchi depth, alkalinity, and bank slope. Dipterans and oligochaetes were the most common collector-gatherers. Both predator and gatherer percentages were highly variable across sites and their abundances were strongly antagonistic (Figure 2). There was an almost complete lack of the filterer and shredder functional groups.

Evenness and the percentage of insect taxa were highly variable across the lakes but were not correlated to any of the variables examined in this study. The HBI showed very little variability and indicated that all of the lakes were in poor condition (Appendix 2). Finally, the EPT and percent intolerant taxa metrics were not useful because there were very few Ephemeropterans and Trichopterans and no Plecopterans. 


\section{Discussion}

Macroinvertebrate Assemblages

The often very high abundances of oligochaetes and chironomids found in the littoral zones of theses lakes are typical of many freshwater systems. Studies of the littoral zone macroinvertebrates of numerous lakes, including those in Wisconsin (Beckett and others, 1990), Michigan (Mittlebach, 1981), New Jersey (Dougherty and Morgan, 1991), and New Zealand (Weatherhead and James, 2001) were comprised predominantly of oligochaetes and chironomids. These taxa were also found to be very abundant in some prairie wetlands (Zimmer and others, 2001) and higher order streams and rivers (Barton, 1980; Quinn and Hickey, 1990).

This wide distribution of oligochaetes and certain chironomid taxa is partially because of their ability to persist among unstable substrates (Weatherhead and James, 2001; Barton, 1980). Unstable substrates are areas of high disturbance that include the shifting coarse sands of rivers and stream pools and the muddy silt and fine sand which frequently comprise the substrates of wetlands and enriched lakes. Much of the littoral habitat of the strip mine lakes in this study consisted of unstable mud and silt, so it would have been unusual if oligochaetes and chironomids were not prevalent.

The other taxon that had frequent high abundances in the mining lakes was the amphipod Hyallela sp. This is a widely distributed group throughout freshwater environments, often being more abundant in cooler water that is not eutrophic. Hanson (1990) found while studying two different aquatic habitats that amphipods were the dominant macroinvertebrate among rooted macrophytes and that they were much less common among beds of the algae Chara. 
An interesting phenomenon was that Hyallela sp. was only abundant in lakes with excessive concentrations of the herbicide atrazine. Atrazine is a broad-leaf herbicide which prevents photosynthesis and has been used extensively for the past forty years to increase the growth of corn and soybeans, especially in the Midwest. For context, the USEPA set the safe drinking water limit for atrazine at $3 \mathrm{ppb}$ (Dodson and others, 1999). In spring 2003, lake L1 had a mean concentration of $994 \mathrm{ppb}$ (Appendix 4). The mean throughout the lakes in this study was $307 \mathrm{ppb}($ S.E. $=71.02)$. Of the six lakes $(\mathrm{L} 1, \mathrm{~S} 5$, $\mathrm{S} 8, \mathrm{~S} 9, \mathrm{~S} 10, \mathrm{~S} 11$ ) in which $>15 \%$ of the three hundred invertebrates identified were Hyallela, five had mean concentrations of $>300 \mathrm{ppb}$ of atrazine. Lake S10 was the only lake which did not fit into this pattern with a mean concentration of $57.21 \mathrm{ppb}$ of atrazine and $>60 \%$ Hyallela. Lakes S8-S11 were all adjacent to agricultural plots and were connected by drain pipes and ditches.

Initially, I believed this pattern occurred because of a bottom-up type trophic cascade. It seemed that the high atrazine concentrations were preventing algae from photosynthesizing, which would lead to the possibility of a better oxygenated habitat more suitable for Hyallela. The Hyallela-atrazine relationship must be more complex, however, as lakes such as L2 and L3 had higher concentrations of atrazine but did not have very abundant populations of Hyallela. Another factor to consider is that when I ran the multiple regressions, chlorophyll $a$ and atrazine both appeared to have a positive relationship with the predator functional group. This is a very unusual relationship for a chemical that would prevent the formation of chlorophyll $a$. It could not be determined whether atrazine was solely responsible for the high abundances of Hyallela or whether numerous factors were working in unison, such as macrophyte biomass or sunfish 
abundance. An enclosed mesocosm experiment would better clarify the results of atrazine on this aquatic faunal structure.

In order to more completely understand how the littoral zones of these lakes are utilized by macroinvertebrates and also how the communities of these invertebrates differ from other regional lakes, it would be helpful to analyze samples taken from different areas within the littoral habitat. For example, Weatherhead and James (2001) separated the lentic littoral zone into four different areas: a shallow wave-swept zone that has fauna similar to streams; a zone beneath this which contains the rooted macrophytes; a detritus rich zone underneath the macrophytes; and a sub-littoral zone in which sunlight barely penetrates and rooted macrophytes do not appear. Analyzing each of these four zones separately would provide a more thorough representation of the fauna of the littoral macroinvertebrates than analyzing them as an aggregate. Separate analyses would also facilitate more detailed comparisons between invertebrates and habitat variables in these lakes and would be valuable tools for determining how these communities compare with those of other aquatic habitats.

\section{Bioassessment Metrics}

Taxa richness increased as the percentage of macrophyte cover and the abundance of sunfish increased. Previous studies indicate that invertebrate abundance is often increased among macrophytes (Mittlebach, 1981; Hanson, 1990; Merrit and Cummins, 1996) due to increased heterogeneity and refuge from predators. Also, different species of macrophytes support different communities and abundances of invertebrates (Hanson, 
1990), so better resolution of the littoral zone macrophytes in this study would have likely been more meaningful than the percentage of cover alone.

Sunfish frequently feed on littoral zone macroinvertebrates, but whether they actively regulate prey communities is still debatable. Results on biomass, density, and composition of littoral invertebrates have been highly variable, but most studies indicate that the overall effects are minimal (Pierce and Hinrichs, 1997; Zimmer and others, 2001). A common occurrence is an increase in the numbers of small invertebrates, as larger animals are more easily predated on. The minimal impacts on invertebrate communities are often attributed to the defense mechanisms of macroinvertebrates as well as the use of refugia (Mittlebach, 1981; Crowder and Cooper, 1982; Gilinsky, 1984; Pierce and Hinrichs, 1997; Zimmer and others, 2001). It seems likely in this study that habitats with more macrophytes were conducive to both macroinvertebrate and sunfish communities and may have been responsible for the relationship.

Lake area and the percentage of rocky substrate strongly affected dominance and diversity metrics. Larger lakes with rocky substrates were more diverse and less dominated by a single taxon. An experiment by Schmude and others (1998) compared the invertebrate communities of complex three-dimensional artificial substrates, which were similar to rip-rap, to simpler two-dimensional substrates. Their study showed significantly higher abundances and richness in the complex substrates, which they believed was due to the greater heterogeneity, surface complexity, interstitial space, and surface area of the complex substrates. These factors and an increased substrate stability may also explain the increase in diversity that I found among rock and gravel substrates in the strip-mine lakes. 
I found no literature that linked macroinvertebrate communities to lake size, but the appearance of lake area as a diversity factor may be a result of the decreased temperature fluctuations and lower nutrient loads that accompany larger and deeper bodies of water.

The Simpson diversity metric also increased as the littoral slope decreased. The steepness of the littoral slope has been identified as a limiting factor of macrophyte biomass, which in turn is linked to richness and diversity. One example of this relationship was done by Duarte and Kalff (1986) in which it was found that macrophyte biomass decreased as the littoral slope steepened. They suggested this relationship was likely a result of the erosional nature of steep slopes which causes much of the organic sediments to be transported away from the littoral zone to the deeper areas of a lake. A gentle slope, on the other hand, better retains fine organic sediment while providing a more stable substrate. Additionally, areas of gentle sloping littoral zones have increased surface area in the photic zone, which increases the area of habitat usable by rooted macrophytes.

I found an interesting strong inverse relationship between predator and gatherer functional groups (Figure 2) which shows that these two groups dominated the macroinvertebrate communities of these systems. Shredder taxa, which feed on coarse (>1mm) particulate organic matter (Cummins, 1973; Cuffney and others 1990), never comprised more than $5 \%$ of the taxa in any lake and were absent in many samples altogether. Scrapers and filterers were even less commonly found in these lakes. In addition to being nearly the only functional groups represented by macroinvertebrates, predators and gatherers were possibly influencing each other as their 
strong relationship allows little space for interaction with other functional groups. The antagonistic nature of their abundances indicates that the predacious invertebrates and the gatherers were never in high abundance simultaneously. From these results, I cannot determine if the predacious invertebrates were actively feeding on the gatherers or whether the prevailing conditions of the lakes provided a good habitat for one functional group while simultaneously being a poor habitat for the other. The physical properties of the lakes was indeed a likely factor for determining functional group structure, as predators were positively correlated with alkalinity and concentrations of chlorophyll $a$ and atrazine, while the gatherers were negatively correlated to these same variables (Table 1).

Combining bioassessment metrics into a comprehensive multimetric index was impractical due to the absence of adequate reference conditions. These lakes are all artificial and highly impacted, so none can represent a least disturbed condition which is most recommended as a reference (Gerritson and others, 1998). Choosing a best possible condition for use as a reference, the usual alternative for artificial systems (Gerritson and others, 1998), is also not recommended. The lack of comparable data would cause the comparison to occur only among the lakes within this small area and would not prove meaningful for wider range comparisons.

\section{Summary}

This study was the first attempt to describe the macroinvertebrate communities of the littoral areas of Midwestern strip-mine lakes. I showed that the taxa that were present were similar to those in enriched lakes and large rivers. Richness and diversity increased 
as habitat heterogeneity increased with more vegetation and rocky substrate, and also increased with larger lake areas. Predators and gatherers were inversely correlated with each other and were the only functional groups well represented by macroinvertebrates. I also found that certain bioassessment metrics that were developed for stream macroinvertebrate communities were also applicable to these strip mine lakes. These results should prove beneficial to future monitoring of the site. Additionally, I believe that there is potential for full bioassessments, which include reference conditions and integrated biotic indices. This would make benthic macroinvertebrates a very useful and inexpensive method for monitoring the condition of mining lake systems.

\section{Acknowledgements}

Research was funded by the Illinois National Guard and a grant from the Southern Illinois University Office for Research Development and Administration (ORDA). The assistance and patience of M. Whiles is much appreciated. K. Coles, J. Garvey, D. Knuth, M. Lydy, and B. Tetzlaff provided water toxicology, fish, and sediment data. J. Reeve assisted with statistical analyses. M. Flinn, S. Peterson, and D. Walther provided assistance and advice throughout the collection and identification process.

\section{Literature Cited}

Anderson, M.T., and C.L. Hawkes 1985, Water Chemistry of Northern Great Plains strip mine and livestock water impoundments. Water Resour. Bull. 21:499-505.

Barbour, M.T., J. Gerritson, B.D. Snyder, and J.B. Stribling 1999. Rapid bioassessment protocols for use in wadeable streams and rivers: periphyton, benthic macroinvertebrates, and fish. U.S. Environmental Protection Agency 841-D-99-002.

Barton, D.R. 1980. The macroinvertebrate communities of the Athabasca River near Ft. Mackay, Alberta. Hydrobiologia 74, 151-160.

Baxter, R.M. 1997. Environmental effects of dams and impoundments. Annu. Rev. Ecol. Syst. 8:255-283.

Beckett, D.C., T.P. Aartila, and A.C. Miller 1990. Contrasts in density of benthic invertebrates between macrophyte beds and open littoral patches in Eau Galle Lake, Wisconsin. Am. Midl. Nat. 127:77-90.

Boisclaire, D. and W.C. Leggett 1985. Rates of food exploitation by littoral fishes I a mesotrophic northtemperate lake. Can. J. Fish. Aquat.Sci. 42:556-566. 
Castro, J.M. and J.N. Moore 2000. Pit lakes: their characteristics and the potential for their remediation. Env. Geo. 39 (11) 1254-1260.

Crowder, L.B. and W.E. Cooper 1982. Habitat structural complexity and the interactions between bluegills and their prey. Ecology 63(6):1802-1813.

Cuffney, T.F., J.B. Wallace, and G.J. Lugthart 1990. Experimental evidence quantifying the role of benthic invertebrates in organic matter dynamics of headwater streams. Freshwat. Biol,. 23:281-299.

Cummins, K.W. 1962. An evaluation of some techniques for the collection and analysis of benthic samples with special emphasis on lotic waters. Amer. Midland Nat. 76:477-504.

Cummins, K.W. 1973. Trophic relations of aquatic insects. Ann. Rev. Ent. 18:183-206.

Davis, A. and L.E. Eary 1997. Pit lake water quality in the western United States: an analysis of chemogenetic trends. Min. Eng. 49:98-102.

Dodson, S.I., C.M. Merrit, J.P. Shannahan, and C.M. Shults 1998. Low exposure concentrations of atrazine increase male production in Daphnia pulicaria. Environmental Toxicology and Chemistry, Vol. 18, No. 7, 1568-1573.

Dougherty, J.E. and M.D. Morgan 1991. Benthic community response (primarily Chironomidae) to nutrient enrichment and alkalinization in shallow, soft water humic lakes. Hydrobiologia 215:73-82.

Doyle, G.A. and D.D. Runnels 1997. Physical limnology of existing mine pit lakes. Min. Eng. 49:31-36

Duarte, C.M. and J. Kalff 1986. Littoral slope as an indicator of the maximum biomass of submerged macrophyte communities. Limnol. Oceanogr., 31(5):1072-1080.

Duarte, C.M. and J. Kalff 1990. Patterns in the submerged macrophyte biomass of lakes and the importance of scale analysis in interpretation. Can. J. Fish. Aquat. Sci. 47:357-363.

Gerritson, J., R.E. Carlson, D.L. Dycus, C. Faulkner, G.R. Gibson, J. Harcum, and S.A. Markowitz, 1998. Lake and reservoir bioassessment and biocriteria: technical guidance document. USEPA Office of Water. EPA 841-B-98-007.

Gilinsky, E. 1984. The role of fish predation and spatial heterogeneity in determining benthic community structure. Ecology 65:455-468.

Hanson, J.M. 1990. Macroinvertebrate size-distributions of two contrasting freshwater macrophyte communities. Freshwater Biology 24:481-491.

Hilsenhoff, W.L. 1987. An improved biotic index of organic stream pollution. Great Lakes Entomologist, 20:31-39.

Huchinson, G.E. 1957. A Treatise on Limnology. Vol. I. J. Wiley and Sons, Inc. N.Y.

Merrit, R.W. and K.W. Cummins. An Introduction to the Aquatic Insects of North America, $3^{\text {rd }}$ ed. 1996.

Kendall/Hunt, Dubuque.

Miller, G.C., W.B. Lyons, and A. Davis 1996. Understanding the water quality of pit lakes. Env. Sci. Tech. Vol. 30 \#3: 118A-123A.

Mittlebach, G.G. 1981. Patterns of invertebrate size and abundance in aquatic habitats. Can. J. Fish. Aquat. Sci., 38:896-904. 
Pierce, C.L. and B.D. Hinrichs 1997. Response of littoral invertebrates to reduction of fish density: Simultaneous Experiments in Ponds with Different Fish Assemblages. Freshwater Biology 37:397-408.

Quinn, J.M. and C.W. Hickey 1990. Characterisation and classification of benthic invertebrate communities in 88 New Zealand rivers in relation to environmental factors. N.Z. Mar. Freshwat. Res. 24:387-409.

Rosenberg, D.M., P. McCully, and C.M. Pringle 2000. Global-scale environmental effects of hydrological alterations: Introduction. Bioscience 50:746-751.

Schmude, K.L., M.J. Jennings, K.J. Otis, and R.P. Piette 1998. Effects of habitat complexity on macroinvertebrate colonization of artificial substrates in north temperate lakes. J. N. Am. Benthol. Soc. 17(1):73-80.

Smith, D.G. 2001. Pennak's Freshwater Invertebrates of the United States: Porifera to Crustacea, $4^{\text {th }}$ ed. Wiley and Sons, New York.

Thornton, K.W., B.L. Kimmel, and F.E. Payne, eds. 1991. Reservoir Limnology: Ecological Perspectives. John Wiley \& Sons, New York. 246 pp.

Weatherhead, M.A. and M.R. James 2001. Distribution of macroinvertebrates in relation to physical and biological variables in the littoral zone of nine New Zealand Lakes. Hydrobiologia 462:115-129.

Wetzel, R.G. 2001. Limnology: Lake and River Ecosystems. $3^{\text {rd }}$ ed. Academic Press, San Diego. 1006 pp.

Whiles, M.R., B.L. Brock, A.C. Franzen., and S.C. Dinsmore II 2000. Environmental auditing: stream invertebrate communities, water quality, and land-use patterns in an agricultural drainage basin of northeastern Nebraska, USA. Environmental Management, Vol. 26, No. 5, 563-576.

Zimmer, K.D., M.A. Hanson, M.G. Butler, and W.G. Duffy 2001. Size distribution of aquatic invertebrates in two prairie wetlands, with and without fish, with implications for community production. Freshwater Biology 46:1373-1386. 
Table 1 Results of multiple regression models between environmental variables and diversity metrics. +/indicates positive/negative relationship.

\begin{tabular}{|c|c|c|c|c|c|}
\hline & $\mathbf{R}^{2}$ & Adjusted $\mathbf{R}^{2}$ & $\boldsymbol{P}$ & $P$ Leverage & Independent Variable \\
\hline Total Richness & 0.91 & 0.85 & 0.0010 & $\begin{array}{l}0.0007 \\
0.0010\end{array}$ & $\begin{array}{l}+ \text { Sunfish Abundance } \\
+\% \text { Vegetation }\end{array}$ \\
\hline Dominance & 0.63 & 0.56 & 0.0040 & $\begin{array}{l}0.0027 \\
0.0055\end{array}$ & $\begin{array}{l}\text { - \% Rock/Gravel } \\
\text { - Lake Area }\end{array}$ \\
\hline $\begin{array}{l}\text { Simpson } \\
\text { Diversity }\end{array}$ & 0.92 & 0.88 & 0.0003 & $\begin{array}{r}<0.0001 \\
<0.0001 \\
0.0007 \\
0.0019 \\
0.0060\end{array}$ & $\begin{array}{l}\text { + Lake Area } \\
+\% \text { Rock/Gravel } \\
\text { - Slope } \\
+ \text { Simazine } \\
\text { - Secchi }\end{array}$ \\
\hline $\begin{array}{l}\text { Shannon } \\
\text { Diversity }\end{array}$ & 0.60 & 0.53 & 0.0060 & $\begin{array}{l}0.0041 \\
0.0077\end{array}$ & $\begin{array}{l}+\% \text { Rock/Gravel } \\
+ \text { Lake Area }\end{array}$ \\
\hline$\%$ Predator & 0.89 & 0.83 & 0.0018 & $\begin{array}{l}0.0005 \\
0.0013 \\
0.0033 \\
0.0077\end{array}$ & $\begin{array}{l}\text { + Chlorophyll a } \\
+ \text { Alkalinity } \\
\text { + atrazine } \\
+ \text { Sunfish Abundance }\end{array}$ \\
\hline$\%$ Gatherer & 0.83 & 0.73 & 0.0055 & $\begin{array}{l}0.0019 \\
0.0043 \\
0.0109 \\
0.0193 \\
0.0262\end{array}$ & $\begin{array}{l}\text { - Chlorophyll. a } \\
\text { - Alkalinity } \\
\text { - atrazine } \\
\text { - Secchi } \\
\text { - Slope }\end{array}$ \\
\hline
\end{tabular}




\section{List of Figure Captions}

Figure 1. Aerial photograph of the Sparta Illinois National Guard Training Facility.

Figure 2 Correlation between percent predator and percent collector-gatherer taxa 


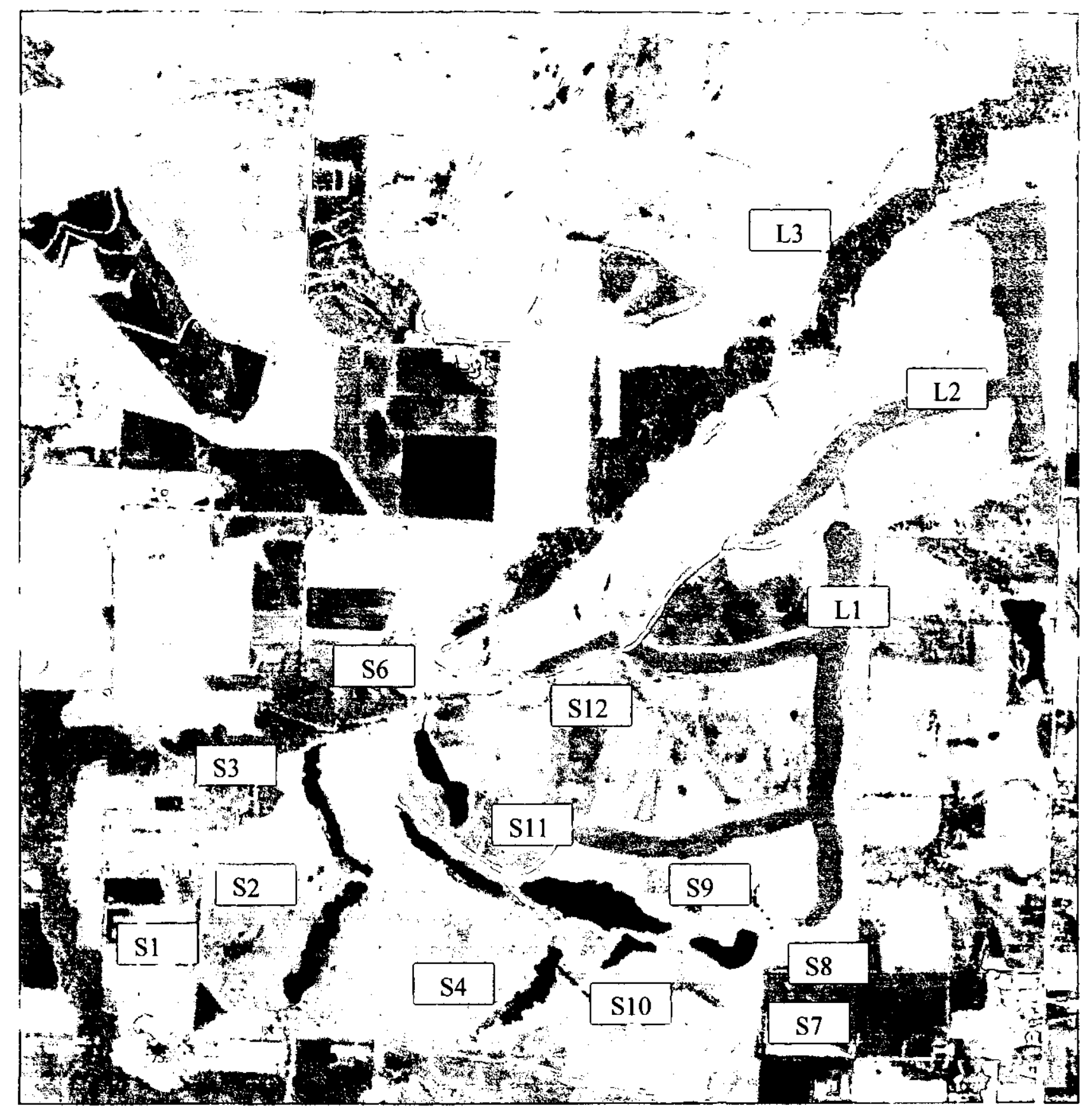

Figure 1. 


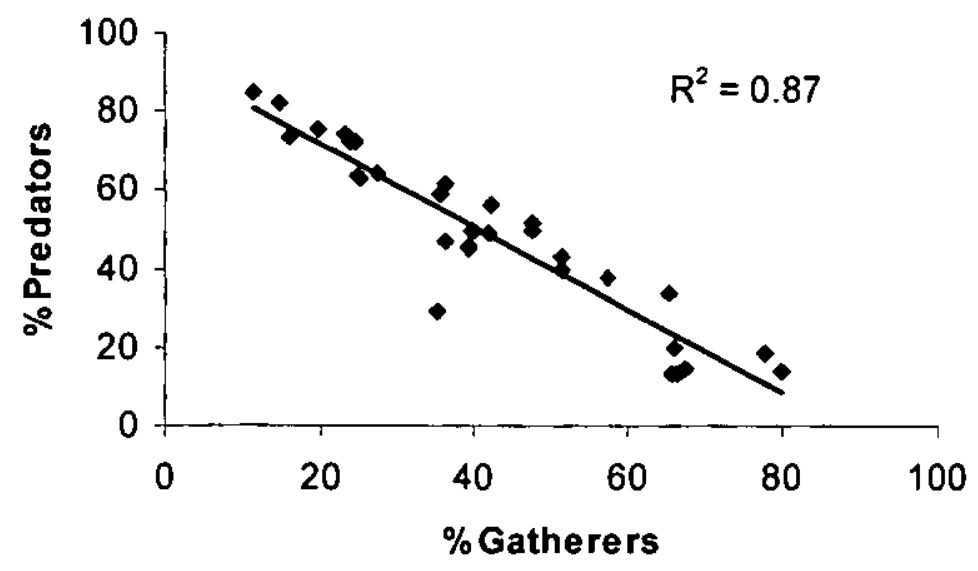

Figure 2 
Appendix 1. Taxonomic distribution of the littoral macroinvertebrates in the lakes of the Sparta, Illinois National Guard Training Facility

\begin{tabular}{|c|c|c|c|c|c|c|c|c|c|c|c|c|c|c|c|c|c|c|c|c|c|c|c|c|c|c|c|c|c|c|c|c|c|}
\hline $\begin{array}{l}\text { Lake } \\
\text { Sample }\end{array}$ & $\begin{array}{l}\text { L1 } \\
A\end{array}$ & B & c & $\begin{array}{c}\text { L2 } \\
\text { A }\end{array}$ & B & c & $\stackrel{\mathrm{L3}}{\mathrm{A}}$ & B & C & $\begin{array}{c}\text { S2 } \\
\text { A }\end{array}$ & B & $\begin{array}{c}\mathbf{S 3} \\
A\end{array}$ & B & $\begin{array}{l}\text { S4 } \\
\text { A }\end{array}$ & B & $\begin{array}{l}\text { S5 } \\
\text { A }\end{array}$ & B & $\begin{array}{l}\text { S6 } \\
\text { A }\end{array}$ & B & $\begin{array}{c}\text { S7 } \\
\text { A }\end{array}$ & B & $\begin{array}{l}58 \\
A\end{array}$ & B & $\begin{array}{l}\text { So } \\
A\end{array}$ & B & $\begin{array}{c}\text { S10 } \\
A\end{array}$ & B & $\begin{array}{c}\text { S11 } \\
\text { A }\end{array}$ & B & $\begin{array}{c}S 12 \\
A\end{array}$ & B & & $\%$ of overall \\
\hline Eolostoma & & & & & & & & & & & & & & 2 & & & & & & & & & & & & & & & & & & 2 & 0.0003 \\
\hline Berosus & & & & & & 1 & & & 1 & & & & 1 & & & $T$ & & & & & & & & & & & & & & & & 4 & 0.0005 \\
\hline Bezzia/Polyomia & & & & & & & & 1 & & & & & & & & 1 & & & & & & & & & & & & & & 3 & 1 & 6 & 0.0008 \\
\hline Caecidotea & & & & & & & & & & & & 1 & & & & & & 2 & & & & 1 & & & & & & & & & 1 & 5 & 0.0007 \\
\hline Caenls & 7 & 1 & & 58 & 58 & 19 & 6 & 40 & 4 & & 1 & 6 & 19 & 2 & 22 & 17 & 19 & 16 & 18 & 2 & 1 & 17 & 6 & 8 & 44 & 13 & 5 & 13 & 30 & & 14 & 468 & 0.0616 \\
\hline Câtilbatis & & 1 & & 1 & & 1 & & 4 & & & & 17 & & & & -1 & 2 & 5 & 1 & & & & & 6 & & & & & & & & 34 & 0.0045 \\
\hline Cambaridae & 2 & 3 & 1 & 1 & & & & 2 & 1 & & & 5 & & 1 & & $\frac{1}{1}$ & & 3 & 4 & 2 & 2 & & & & & 1 & & 1 & & & 1 & 31 & 0.0041 \\
\hline Chironomidae & 32 & 49 & 23 & 5 & 16 & 20 & 43 & 97 & 102 & 38 & 67 & 5 & 30 & 38 & 227 & 29 & 10 & 38 & 15 & 13 & 24 & 1 & 2 & 22 & B & 4 & 6 & 5 & 10 & 5 & 20 & 1002 & 0.1326 \\
\hline Collembola & 5 & & & 3 & 4 & & & 6 & 57 & & & & & 1 & & 7 & 2 & & & & & & & & & & & & & & & 85 & 0.0112 \\
\hline Coptotomus & & & & & & & 1 & & & & & & & & & & & & & & & & & & & & 1 & & & & & 2 & 0.0003 \\
\hline Dineutus & & & & & & & 1 & $E$ & 2 & & & & & $\therefore$ & 4 & & $\leftarrow$ & & & & & & & & 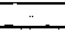 & & & & & & & 7 & 0.0009 \\
\hline Dromogomphus & & & & & & & & & & & 1 & & & & & & & & 1 & & & & 1 & & & & & & & & & 3 & 0.0004 \\
\hline Enallagma & 29 & 1 & & 12 & 14 & 17 & & 2 & & 1 & & 3 & & 6 & 1 & 6 & 30 & & 10 & & & 3 & & 1 & 1 & 5 & 4 & 2 & 4 & 7 & 5 & 164 & 0.0217 \\
\hline Erpobdella & & & & & & & & & & & & & & & & & & & & & 1 & & & & & & 1 & & & & & 2 & 0.0003 \\
\hline Fosssaria & 1 & 7 & 1 & 6 & 3 & & & & 1 & 2 & 1 & & & & 1 & 15 & & & & & & & & 1 & & & & & & & & 39 & 0.0052 \\
\hline Haliplüs & & & 1 & & & & 5 & 2 & & & 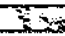 & & & & & & $\infty$ & & & & & & & & & & & & & 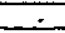 & & 8 & 0.0011 \\
\hline Holisoma & 5 & 41 & & 6 & 8 & 8 & & & 1 & 8 & & 1 & 1 & & 7 & 7 & 11 & 1 & & & & 1 & & & 3 & 22 & 24 & 4 & 4 & & & 183 & 0.0216 \\
\hline Hexagenia & & & & & & & & 1 & & & & & & & & & & 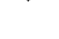 & & & & . & & & 1 & 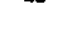 & 2 & 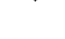 & 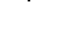 & 1 & 1 & 4 & 0.0005 \\
\hline Hyallela & 58 & 49 & 10 & 44 & 16 & 51 & 6 & 5 & 3 & 26 & & 10 & 13 & 1 & & 73 & 34 & 5 & 1 & 28 & 7 & 186 & $9 \theta$ & 188 & 253 & 177 & 189 & 59 & 58 & 3 & 48 & 1680 & 0.2223 \\
\hline Hydroporus & 5 & & & 1 & 2 & & 2 & & 3 & 2 & 2 & & 2 & & & & 6 & & & & & 5 & & 6 & 2 & 5 & & & & & 1 & 44 & 0.0058 \\
\hline Hymanolla/Phagoca & & & & 1 & 1 & & 4 & & 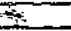 & 7 & 5 & & & & & 3 & 3 & & & & & 7 & & & & 1 & & & 1 & & & 33 & 0.0044 \\
\hline Libelluia & 12 & 3 & 1 & 1 & & 2 & & & 1 & & 1 & 1 & & & & & 1 & & & 3 & 2 & 4 & 8 & & 2 & 1 & & & & & & 43 & 0.0057 \\
\hline Mesovelia & & & & & & & & & & & & & & & & & & & & & & & & & & & & & & & 10 & 10 & 0.0013 \\
\hline Microvella & & & & & & & & & 6 & & & & & & & & & & & & & & & & & & & & & & & 8 & 0.0008 \\
\hline Noctopayche & & & & 1 & & 1 & & & & & & & & & & & & & & & & & & & & & & & 1 & 1. & & 4 & 0.0005 \\
\hline Nemotêlus & & & & & & & & & & & & 1 & & & & & $\because$ & & & & & & & & & & & & & & & 1 & 0.0001 \\
\hline Odontomyla/Hedrio & discus & & & & & & & & & & & 1 & & & & & & & & & & & & & & & & & & & & 1 & 0.0001 \\
\hline Oecetls & & & & & & & & 1 & & & & & & & 1 & 2 & & & & & & & & & & & 1 & 1 & & & 6 & 12 & 0.0016 \\
\hline Ollgochatata & 91 & 77 & 49 & 172 & 164 & 127 & 138 & 73 & 78 & 188 & 81 & 69 & 123 & 28 & 19 & 130 & 179 & 35 & 20 & 249 & 264 & 23 & 137 & 20 & 10 & 51 & 36 & 121 & 194 & 13 & 32 & 2992 & 0.3958 \\
\hline Oxyethire & 4 & 8 & & & & & & & & & & & & & & & & & & & & & & & & & & & & & & 12 & 0.0016 \\
\hline Paracymus & & & & & & & & & & & & & $=$ & & & & & & & & & & & & & 1 & & & & & & 1 & 0.0001 \\
\hline Paraplea & & & & & & & & & 1 & & & & & & & & & & & & & & & 1 & & & & & & & & 2 & 0.0003 \\
\hline Peltodytes & 6 & 1 & 1 & 1 & & & 4 & 4 & 3 & & & 5 & 2 & & & & & & 1 & & & & & 1 & & 1 & 2 & & 1 & 1 & & 34 & 0.0045 \\
\hline Physa & 12 & 57 & & 11 & 22 & 6 & 18 & 37 & 41 & 25 & & & & 2 & 10 & 10 & 16 & 2 & 5 & 13 & 12 & 82 & 52 & 56 & $\theta$ & 38 & 37 & 13 & 7 & 1 & 2 & 596 & 0.0788 \\
\hline Placobdella & & & & & & & 1 & & & & & & & & & & & & & & & 1 & & & & & & & & & & 2 & 0.0003 \\
\hline Ranatra & & & & & & & & & & & & & & & 1 & & & & & & & & 1 & & & & & & & & & 2 & 0.0003 \\
\hline Sepodon & & & & & & & & & $\overline{1}$ & & & & & 1 & & & & & & & & & & & & & & & & & & 2 & 0.0003 \\
\hline Sphaerium & & & & & & & & & & & & & & & & & & & & 2 & 1 & 2 & & 13 & 8 & & & & & & & 26 & 0.0034 \\
\hline Stenonema & & & & & & & & 1 & 1 & & & & 2 & & & & & & 2 & & & & & & & & & & & & & 6 & 0.0008 \\
\hline Stratiomys & & & & & & & & & & & & 1 & & & & & & & & & & & & & & & & & & & & 1 & 0.0001 \\
\hline Tiflchocorixa & & & & 1 & & & & & 1 & & & & 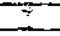 & & 1 & 10 & 3 & & & & & & & & & & & 2 & 2 & & & 20 & 0,0026 \\
\hline Tropisternus & & & & & & & & & & & & 1 & 1 & & & & & & & & & & & & & & & & & & & 2 & 0.0003 \\
\hline
\end{tabular}




\section{Appendix 2. Summary of the bioassessment metric-results}

\begin{tabular}{|c|c|c|c|c|c|c|c|c|c|c|c|}
\hline Lake and Sample & $\begin{array}{l}\text { Species } \\
\text { Richness }\end{array}$ & $\begin{array}{l}\text { Shannon } \\
\text { Diversity }\end{array}$ & $\begin{array}{l}\text { Shannon } \\
\text { Evenness }\end{array}$ & $\begin{array}{c}\text { HBI } \\
\text { Value }\end{array}$ & $\%$ Oligochaeta & $\%$ Chironomidae & $\%$ Gatherers & $\%$ Predators & $\begin{array}{c}\text { EPT } \\
\text { Richness }\end{array}$ & $\begin{array}{l}\text { Simpson } \\
\text { Diversity }\end{array}$ & $\%$ Dominance \\
\hline L1-A & 14.00 & 1.99 & 0.14 & 8.99 & 0.34 & 0.12 & 0.40 & 0.51 & 2.00 & 0.19 & 0.34 \\
\hline$B$ & 13.00 & 1.89 & 0.74 & 7.68 & 0.26 & 0.16 & 0.29 & 0.35 & 3.00 & 0.18 & 0.26 \\
\hline C & 8.00 & 1.18 & 0.15 & 8.29 & 0.56 & 0.26 & 0.56 & 0.42 & 0.00 & 0.39 & 0.56 \\
\hline L2-A & 17.00 & 1.55 & 0.92 & 7.60 & 0.53 & 0.15 & 0.72 & 0.24 & 3.00 & 0.33 & 0.53 \\
\hline B & 11.00 & 1.53 & 0.14 & 7.58 & 0.53 & 0.52 & 0.73 & 0.16 & 1.00 & 0.33 & 0.53 \\
\hline C & 11.00 & 1.55 & 0.15 & 7.96 & 0.52 & 0.80 & 0.59 & 0.36 & 3.00 & 0.38 & 0.52 \\
\hline L3.A & 12.00 & 1.35 & $0 . \overline{11}$ & 7.90 & 0.63 & 0.19 & 0.63 & 0.25 & 1.00 & 0.45 & 0.63 \\
\hline B & 15.00 & 1.74 & 0.12 & 7.73 & 0.26 & 0.35 & 0.45 & 0.39 & 5.00 & 0.23 & 0.35 \\
\hline C & 19.00 & 1.76 & 0.93 & 7.95 & 0.26 & 0.34 & 0.46 & 0.39 & 2.00 & 0.22 & 0.34 \\
\hline S2-A & 9.00 & 1.25 & 0.14 & 8.15 & 0.63 & 0.13 & 0.63 & 0.25 & 0.00 & 0.43 & 0.63 \\
\hline B & 9.00 & 1.39 & 0.11 & 7.89 & 0.56 & 0.42 & 0.52 & 0.48 & 2.00 & 0.43 & 0.56 \\
\hline S3-A & 15.00 & 1.68 & 0.11 & 8.35 & 0.54 & 0.39 & 0.76 & 0.20 & 2.00 & 0.32 & 0.54 \\
\hline$B$ & 1.00 & 1.29 & 0.13 & 7.69 & 0.63 & 0.15 & 0.74 & 0.23 & 2.00 & 0.44 & 0.63 \\
\hline S4-A & 1.00 & 1.41 & 0.14 & 8.85 & 0.34 & $0 . \overline{46}$ & 0.38 & 0.57 & 1.00 & 0.34 & 0.77 \\
\hline B & 11.00 & 0.93 & 0.85 & 7.92 & 0.65 & 0.77 & 0.14 & 0.80 & 2.00 & 0.67 & 0.77 \\
\hline S5-A & 16.00 & 1.84 & 0.12 & 7.97 & 0.42 & 0.93 & 0.50 & 0.40 & 3.00 & 0.24 & 0.42 \\
\hline B & 13.00 & 1.58 & 0.12 & 8.15 & 0.57 & 0.32 & 0.64 & 0.28 & 2.00 & 0.35 & 0.57 \\
\hline$\underline{\mathbf{S}} \mathbf{\underline { A }}$ & 8.00 & 1.48 & 0.18 & 7.74 & 0.34 & 0.37 & 0.50 & 0.48 & 1.00 & 0.28 & 0.37 \\
\hline B & 11.00 & 1.91 & 0.17 & 7.67 & 0.26 & 0.19 & 0.50 & 0.40 & 3.00 & 0.17 & 0.26 \\
\hline S7-A & 8.00 & 0.83 & 0.14 & 8.22 & 0.80 & 0.42 & 0.82 & 0.15 & 1.00 & 0.65 & 0.80 \\
\hline B & 9.00 & 0.67 & 0.75 & 8.29 & 0.85 & 0.76 & 0.85 & 0.11 & 1.00 & 0.71 & 0.85 \\
\hline$S 8-A$ & 13.00 & 1.39 & 0.17 & 7.95 & 0.73 & 0.32 & 0.13 & 0.66 & 1.00 & 0.36 & 0.53 \\
\hline B & 8.00 & 1.27 & 0.16 & 7.99 & 0.45 & 0.65 & 0.47 & 0.36 & 3.00 & 0.33 & 0.45 \\
\hline S9-A & 12.00 & 1.41 & 0.12 & 8.00 & 0.62 & 0.68 & 0.15 & 0.67 & 2.00 & 0.38 & 0.58 \\
\hline B & 11.00 & 0.98 & 0.89 & 7.86 & 0.29 & 0.18 & 0.19 & 0.78 & 2.00 & 0.58 & 0.75 \\
\hline$\$ 10-A$ & 13.00 & 1.46 & 0.11 & 7.97 & 0.16 & 0.13 & 0.20 & 0.66 & 1.00 & 0.35 & 0.55 \\
\hline B & 11.00 & 1.29 & 0.12 & 8.00 & 0.12 & 0.20 & 0.13 & 0.66 & 2.00 & 0.42 & 0.62 \\
\hline S11-A & 11.00 & 1.34 & 0.13 & 7.86 & 0.55 & 0.23 & 0.62 & 0.36 & 2.00 & 0.37 & 0.55 \\
\hline B & 11.00 & 1.23 & 0.11 & 7.70 & 0.62 & 0.33 & 0.72 & 0.24 & 3.00 & 0.44 & 0.62 \\
\hline S12-A & 9.00 & 1.80 & 0.20 & 7.70 & 0.37 & 0.14 & 0.43 & 0.51 & 2.00 & 0.19 & 0.37 \\
\hline B & 13.00 & 1.88 & 0.14 & 7.86 & 0.23 & 0.15 & 0.34 & 0.65 & 3.00 & 0.20 & 0.34 \\
\hline Overall Mean & 11.06 & 1.45 & 0.27 & 7.98 & 0.47 & 0.36 & 0.49 & 0.42 & 1.97 & 0.37 & 0.54 \\
\hline Standard Error & 0.70 & 0.06 & 0.05 & 0.06 & 0.03 & 0.04 & 0.04 & 0.03 & 0.19 & 0.03 & 0.03 \\
\hline
\end{tabular}




\section{Appendix 3: Physical habitat assessment results}

\begin{tabular}{|c|c|c|c|c|c|c|c|c|c|c|}
\hline \multirow[b]{2}{*}{ Lake and Sample } & \multicolumn{2}{|c|}{ Vegetation } & \multirow[b]{2}{*}{$\begin{array}{c}\% \text { Shade } \\
\text { Cover }\end{array}$} & \multirow[b]{2}{*}{$\begin{array}{c}\text { Mean Transect } \\
\text { Depth (M) }\end{array}$} & \multirow[b]{2}{*}{$\begin{array}{c}\text { Bank Slope } \\
\text { (Degrees) }\end{array}$} & \multicolumn{5}{|c|}{$\%$ Substrate Composition } \\
\hline & $\%$ Emergent & $\%$ Submergent & & & & mud & clay & silt & gravel & rock \\
\hline L1-A & & 1 & & 0.324 & 9.36 & & 1 & & & \\
\hline B & 0.5 & 0.8 & & 0.346 & 8.81 & & 1 & & & \\
\hline L.2-A & 0.5 & 0.6 & & 0.384 & 7.69 & & 1 & & & \\
\hline B & & 0.9 & & 0.37 & 5.99 & 0.2 & 0.8 & & & \\
\hline C & 0.2 & 0.3 & & 0.392 & 12.41 & & 1 & & & \\
\hline L3-A & $0 . \overline{45}$ & & 0.75 & 0.522 & 24.23 & & 1 & & & \\
\hline B & 0.3 & & & 0.564 & 11.31 & & 1 & & & \\
\hline c & 0.25 & & 0.81 & 0.51 & 14.57 & & 0.6 & 0.4 & & \\
\hline S2-A & 0.05 & 0.9 & & 0.38 & 13.77 & 0.8 & & 0.2 & & \\
\hline B & 0.05 & 0.95 & 0.19 & 0.578 & 15.11 & 0.4 & & & 0.6 & \\
\hline S3-A & 0.5 & 0.4 & & 0.348 & 8.53 & 0.4 & 0.6 & & & \\
\hline B & 0.1 & 0.2 & & 0.37 & 14.4 & & 0.8 & & & 0.2 \\
\hline$\widehat{\mathbf{S A}-\mathbf{A}}$ & 0.5 & & & 0.534 & 5.43 & & 0.4 & 0.4 & & $\overline{0.2}$ \\
\hline B & 0.1 & & 1 & 0.258 & 3.72 & 0.4 & & 0.6 & & \\
\hline S5-A & & 0.7 & & 0.172 & 11.3 & & 0.8 & & 0.2 & \\
\hline B & & 0.9 & & 0.384 & 11.3 & 0.2 & & & & 0.8 \\
\hline S6-A & & 0.5 & & 0.442 & 12.41 & & 0.2 & 0.2 & & 0.6 \\
\hline B & & 0.5 & & 0.424 & 1.72 & & 0.4 & 0.2 & 0.2 & $\overline{0.2}$ \\
\hline S7-A & 0.1 & & 1 & 0.252 & 7.97 & 0.2 & 0.8 & & & \\
\hline B & 0.5 & 0.4 & 0.6 & 0.174 & 7.13 & 1 & & & & \\
\hline$\widehat{\text { S8-A }}$ & 0.5 & 0.1 & & 0.416 & 2.3 & 0.2 & 0.2 & 0.6 & & \\
\hline B & & 0.2 & & 0.432 & 17.75 & 0.2 & & 0.6 & 0.2 & \\
\hline S9-A & 0.5 & 0.3 & & 0.218 & 6.56 & & 0.8 & & & 0.2 \\
\hline B & & 0.9 & & 0.316 & 14.4 & 0.2 & 0.8 & & & \\
\hline $\mathbf{S 1 0 - A}$ & 0.05 & 0.95 & & 0.526 & 24.94 & & 1 & & & \\
\hline B & & 1 & & 0.514 & 24.7 & & 1 & & & \\
\hline S11-A & & 0.1 & & 0.412 & 12.41 & & 1 & & & \\
\hline B & & 0.5 & & 0.364 & 15.38 & 0.8 & & & & 0.2 \\
\hline S12-A & 0.5 & & & 0.18 & 9.93 & & 0.4 & & 0.6 & \\
\hline B & & & & 0.342 & 15.64 & & & $0 . \overline{6}$ & & 0.4 \\
\hline
\end{tabular}


Appendix 4. Water chemistry, turbidity, and toxicology results

\begin{tabular}{|c|c|c|c|c|c|c|c|c|c|}
\hline Lake & $\begin{array}{l}\text { Secchi } \\
\text { meters }\end{array}$ & $\begin{array}{l}\text { TSS } \\
\mathrm{mg} / \mathrm{L}\end{array}$ & $\begin{array}{c}\text { Alkalinity } \\
\text { mgCaCO3/L }\end{array}$ & $\begin{array}{c}\text { Hardness } \\
\text { mgCaCO3/L }\end{array}$ & $\begin{array}{l}\mathrm{CO} 2 \\
\mathrm{mg} / \mathrm{L}\end{array}$ & $\begin{array}{c}\text { Chlorophyll a } \\
\mu g / L\end{array}$ & $\begin{array}{c}\text { Simazine } \\
\text { ng/L (PPB) }\end{array}$ & $\begin{array}{c}\text { Atrizine } \\
\text { ng/L (PPB) }\end{array}$ & $\begin{array}{l}\text { Metalochlo } \\
\text { ng/L (PPBi) }\end{array}$ \\
\hline L1 & 168 & 21.00 & 105.89 & 179.56 & 12.20 & 1.83 & 63.98 & 993.79 & 0.00 \\
\hline L2 & 117 & 42.89 & 159.22 & 192.78 & 17.67 & 5.77 & 75.40 & 419.60 & 0.00 \\
\hline L3 & 185 & 34.67 & 80.44 & 109.22 & 12.93 & 2.63 & 281.16 & 493.84 & 171.76 \\
\hline S1 & 175 & 40.17 & 131.00 & 164.17 & 15.67 & 5.75 & 67.79 & 323.14 & 0.00 \\
\hline S2 & 236 & 25.00 & 110.00 & 130.83 & 12.03 & 4.40 & 28.65 & 78.62 & 0.00 \\
\hline S3 & 57 & 28.17 & 143.33 & 231.67 & 21.10 & 17.15 & 0.00 & 49.62 & 0.00 \\
\hline S4 & 38 & 42.67 & 240.00 & 298.00 & 23.85 & 36.05 & 19.68 & 58.13 & 0.00 \\
\hline S5 & 48 & 19.50 & 138.67 & 154.00 & 16.50 & 11.30 & 60.76 & 318.05 & 0.00 \\
\hline S6 & 62 & 45.50 & 168.00 & 245.00 & 18.27 & 17.25 & 39.63 & 240.70 & 0.00 \\
\hline$\$ 7$ & 57 & 46.83 & 177.50 & 241.00 & 21.00 & 19.50 & 42.17 & 183.48 & 0.00 \\
\hline S8 & 59 & 34.67 & 148.83 & 189.17 & 7.70 & 28.55 & 38.90 & 374.40 & 0.00 \\
\hline S9 & 74 & 39.33 & 134.17 & 172.00 & 8.77 & 43.20 & 34.95 & 582.26 & 0.00 \\
\hline$\$ 10$ & 87 & 32.50 & 224.17 & 210.67 & 17.90 & 12.45 & 26.11 & 57.21 & 60.44 \\
\hline S11 & 80 & 28.33 & 156.00 & 198.33 & 18.67 & 11.70 & 47.15 & 459.34 & 62.15 \\
\hline $\mathrm{S} 12$ & 54 & 27.83 & 253.17 & 264.00 & 28.07 & 12.70 & 44.02 & 122.83 & 0.00 \\
\hline
\end{tabular}




\section{Appendix 5. Fish Catch Per Unit Effort (60 Minutes)}

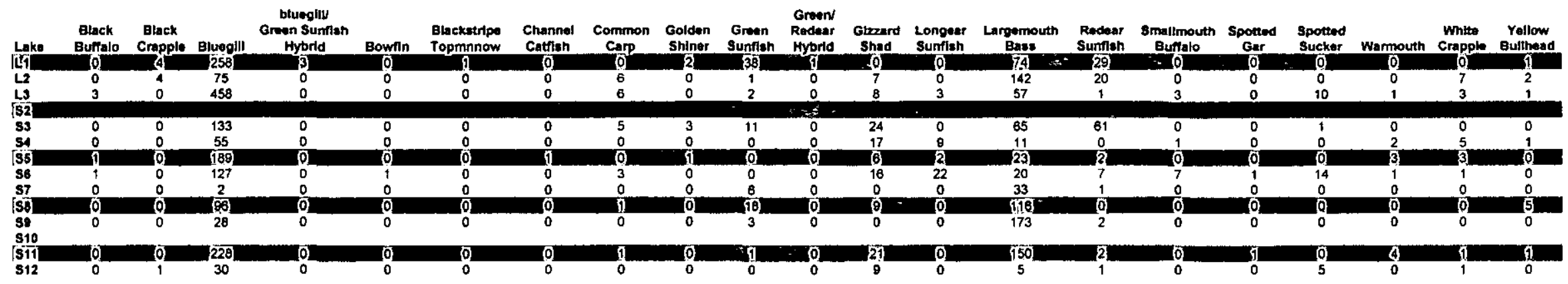

Note: Lakes $\mathbf{S} 2$ and $\mathbf{S} 10$ were covered in ice and not sampled in time for this study 